\title{
TAX REORIENTATION AS CORRUPTION PREVENTION ON INVESTMENT IN INDONESIA
}

\begin{abstract}
Investments, that are supposed to increase the country's economic growth and tax revenues, have potentially created "unofficial" costs for investors and unreported informal income of the bribe recipients. It is important to conduct library research using the new institutionalism theory with historical institutionalism approach in answering the main problem. It is concluded that tax reorientation could prevent corruption on investment in Indonesia. The actors involved in investment, even though, will be limited collectively by government organizations, but the existing restrictions are the design of systems that can influence individuals and groups to prevent corruption. Restrictions of the tax authority can be imposed through several ways, such as enforcing bribes as the non-deductible expense and as an income tax object of gifts to the givers, applying bribes as income to the recipients, recommending non-penal sanctions, and blacklisting the individuals or legal entities involved in corruption.
\end{abstract}

Abstrak: Investasi, yang diharapkan dapat meningkatkan pertumbuhan ekonomi negara dan pendapatan pajak, berpotensi menimbulkan biaya "tidak resmi" bagi investor dan pendapatan informal penerima suap yang tidak dilaporkan. Penting untuk dilakukan studi pustaka dengan menggunakan teori institusionalisme baru dengan pendekatan kelembagaan historis dalam menjawab masalah pokok. Dapat disimpulkan bahwa reorientasi perpajakan dapat mencegah korupsi dalam investasi di Indonesia. Aktor yang terlibat dalam investasi, meskipun akan dibatasi secara kolektif oleh organisasi pemerintah, namun batasan yang ada adalah desain sistem yang dapat mempengaruhi individu dan kelompok untuk mencegah korupsi. Pembatasan otoritas pajak dapat diberlakukan melalui beberapa cara, seperti memberlakukan suap sebagai biaya yang tidak dapat dikurangkan dan sebagai objek pajak penghasilan dari hadiah kepada pemberi, menerapkan suap sebagai pendapatan kepada penerima, merekomendasikan sanksi non-penalti, dan daftar hitam orang perseorangan atau badan hukum yang terlibat korupsi.

\section{Henry Dianto Pardamean Sinaga ${ }^{1}$, Anis Wahyu Hermawan ${ }^{2}$}

${ }^{1}$ Staff of the Directorate General of Taxes, and Doctoral Program of the Diponegoro University, Semarang, Indonesia.

${ }^{2}$ Staff of the Directorate General of Taxes, and Universitas Terbuka, Jakarta, Indonesia.

sinagahenrydp@gmail.com 


\section{Introduction}

In developing countries, such as Indonesia, investment is very important in improving the living standards of the people and in improving the country's economic growth, where one of the real evidences can be seen from the tax revenue that is expected to increase by the state if more and more investment. Of course, in investing their capital, investors are required to comply with laws and regulations in force in Indonesia, and vice versa investors also expect legal certainty for investments that are invested in Indonesia (Himawan, 2003). However, the regulations that apply at present, the supremacy of each law (Act) that applies to investment, as well as regional regulations that also have authority in-licensing and investment have caused a lot of confusion about which laws apply and sometimes "forcing" investors to incur "unofficial" costs, as President of the Republic of Indonesia, Joko Widodo, criticized a number of requirements in the management of licensing regulations and instead led to transactional relations between regulators and the public by stating that "Every rule, every permit, and every requirement has potential to be the object of transactions, objects of corruption "(Saputri \& Minutes, 2017), as well as the results of the disclosure of corruption cases handled by the Corruption Eradication Commission (KPK) in Indonesia stated that almost $80 \%$ of repressive actions taken by KPK related to bribery in the field of licensing (Purbaya, 2019).

Some facts that there has been a lot of from the word orientation, as according to corruption in the field of investment in the Big Indonesian Dictionary (KBBI, 2020) various regions in Indonesia in various online has the meaning as (1) review to forms, including the arrest of the head of the determine the right (right, place, etc.) attitude Office of Investment and Integrated Services (direction, place, etc.); (2) views that of the One Door of PL Regency, AH, underlie thoughts, concerns or tendencies. extorted illegal levies on the issuance of a While the affix "re" in the word corporation's business license in the year "reorientation" has the meaning repeated or 2018 (Akbar, 2018), a Japanese company, returned. Therefore, reorientation can be MC, has agreed to pay a fine of US \$ 85 interpreted as a review of the tendency of million in the United States for bribing a view or thought. In this research, number of officials and politicians in reorientation is interpreted as a review of the Indonesia (including the conviction of an EM views that underlie thinking in the person who received a bribe of US $\$ 375$ thousand) to win a power plant project Tarahan electricity in Lampung (Suparno, 2015), and the conviction of TFT, former (BKPM) in accordance with the decision of the District Court (PN) No. 07/PID.B/TPK/2006/PN.JKT.PST dated August 25, 2006, the decision of the Court of Appeal No. 16/PID/TPK/2006/PT.DKI dated
October 20, 2006, and the Supreme Court (MA) cassation decision No. 103 K/PID/2007 dated 28 February 2007 because it enriched itself using the BKPM Indonesia The importance of investment in mproving the standard of living of the many regulations currently in force that show the supremacy of each regional authority created a great deal of potential legal confusion. incurs "unofficial" costs for investors. Meanwhile, the estuary of every is very closely related to income and costs, wherein the case of the increasing number of economy, it will cause more unreported ncome especially if it comes from informal from fraudulent practices
Abhimanyu, 2009) and more costs are not officially reported by certain entities that provide informal income. This background taxes as a means of preventing corruption in the investment sector in Indonesia. What is meant by reorientation is that the root comes growth, and increasing tax revenue, but the answer the research question: how to reorient 
establishment of an investment law based on Indonesian dictionaries, and Encyclopedias. corruption prevention in Indonesia.

\section{Methodology}

\section{Literature Review}

The problem of corruption in the

This research is qualitative research using expository study. An understanding of the expository study was put forward by Goddard and Melville (2007) who stated that the study was "based purely on existing information, and normally results in" review "-type".

As qualitative research is defined as typically more focused on sense-making in a purer sense, the orientation of this research implies an effort to develop relevant theories from data collected and widely read in the fields of investment and tax, and then compare, contrast, analyze and analyze synthesize all viewpoints qualitatively (Weathington, Cunningham, \& Pittenger, 2012; Goddard \& Melville, 2007). The data used in this study are secondary data, which according to the Judge (Robson \& McCartan, 2016) is "any reanalysis of the data collected by another researcher or organization", thus allowing researchers to concentrate more on analysis and interpretation. Secondary data includes primary legal material, secondary legal material, and tertiary legal material. Primary legal materials, nwhich is binding legal materials consisting of norms (basic) or basic rules, that is Pancasila, the 1945 Constitution of the Republic of Indonesia (1945 Constitution), Law Number 25 of 2007 concerning Capital Investment (Investment Law), Law Number of 16 of 2009 concerning General Provisions and Tax Procedures (Ketentuan Umum dan Tata Cara Perpajakan/KUP Law), Law Number 36 of 2008 concerning the Fourth Amendment to Law No. 7 of 1983 concerning Income Tax (Income Tax Law), Law Number 12 of 2011 concerning the Formation of Regulations and Regulations, tax legislation, and various regulations relating to this writing. Secondary legal materials, which is legal countries where corruption is endemic. Then
materials that provide an explanation of Wei's investigation in 2000 showed that primary legal materials, such as literature, companies paying bribes in the countries textbooks, scientific journals. Tertiary legal where they were involved in Foreign Direct materials, materials that provide instructions Investment (FDI) could serve as additional and explanations for primary and secondary taxes, and the findings of Alfaro et al. in legal materials, such as legal dictionaries, 2008 showed that low institutional quality, 
including corruption, was the main factor the treatment of historical institutionalism in hampering capital flows from rich countries treating stakeholders who have so far been to poor countries (Okada and Samreth, regarded as maximizing self-interest (Shih, 2014). Sun and Wang, 2012; Lowndes, 2010).

In contrast to studies that support the Furthermore, the existence of tax in the argument that corruption has a negative eradication of corruption in the investment impact on a country's investment, some sector stated by Eka (2017) refers to the studies show that FDI has a positive impact preventive and curative side of the tax on economic growth when corruption is institution, where the tax preventive side is severe and has a negative impact if related to its efforts to influence the potential corruption falls below a certain threshold, for the emergence of corrupt behavior such as Okada and Samreth's (2014) study of through tax disincentives while the tax 130 countries during the period 1995 to 2008 curative side is related to the process of which implies that FDI inhibits economic supervision and law enforcement carried out growth in countries where corruption is by the tax authority, the Directorate General below the threshold and encourages of Taxes (DGT), which can be used as a tool economic growth in countries where to detect indications of corruption which can corruption is above, and Egger and Winner's later be followed up by law enforcement 2005 study proves that corruption can be a agencies.

factor that drives FDI inflows, because corruption can help speed up bureaucratic procedures (Okada and Samreth, 2014).

The existence of studies that show the pros and cons related to the relationship of corruption to the investment needs to be investigated qualitatively by using the theory of new institutionalism with the approach of historical institutionalism and by involving the role of taxation. New institutionalism is a response to the scientific study of traditional institutionalism which has so far shown that political institutions (such as government institutions, legislative committees, the judiciary) play a more autonomous role in shaping political impacts for their own good, so they tend to be arenas to fight forces social and only shows itself as a collection of standard operating procedures (SOP) and structures that establish and maintain their own interests (Lowndes, 2010). Then, the adequacy of the approach of historical r institutionalism in this study in connection with its ability to make choices in designing the governance system of an institution that No. 23 of 2014 concerning Regional can influence the decision-making of Government which mandates the transfer of individuals in the future, as well as with government affairs by the central other matters, such as sensitivity to government to autonomous regions based on operations power among the actors involved, the principle of autonomy. This means that the impact of institutional changes initiated the devolution of authority by the central by the tipping point and positive feedback government to political bodies in the regions from the relevant institutions, the interactive cannot be avoided, bearing in mind that the mechanisms underlying these will influence regional head is also elected by the people the choice of actions of individual actors, and concerned, then the decision-making must 
also be carried out by the regional head is "the principle that is open to the right of which is carried out by himself and is the public to obtain true, honest and nonaccountable to the people in his region. The discriminatory information about activities rationalization of decentralization and investment" (where furthermore in Article 2 regional government as a justification for paragraph (3) of Law No. 14 of 2008 delegating the authority of the investment concerning Public Information Openness, it process in the regions to the regional has been formulated that every Public government in the form of assigning Information must be obtained by every assignments, rights, obligations, and Public Information Applicant quickly and on responsibilities for licensing and non- time, at a low cost, and in a simple manner), licensing (Supancana et al., 2010) shows the the principle of accountability which is "the historical facts aligned with the mandate of principle that determines that every activity the related constitution there are social, and the final result of the implementation of economic and political needs related to capital investment must be accountable to the Indonesia's vast territory and large public or the people as holders of the highest population. However, the fact that there have sovereignty of the country in accordance been overlaps in investment rules and with statutory provisions", the principle of overlapping powers between the regions and equal treatment and does not differentiate the central government has led to from the country of origin which is "the decentralization in terms of investment in principle of treatment of non-discrimination Indonesia, which has the potential to become services based on statutory provisions, both an object of corruption. Opportunities for between domestic investors and foreign corruption due to overlapping rules and investors as well as between investors from power in the investment sector are in line one foreign country and investors from other with Mauro's (1995) findings on sampled foreign countries", the principle of countries which show that highly complex togetherness which is "the principle that bureaucratic regulations will always open encourages the role of all investors joint opportunities for corruption, thereby capital in business activities to realize the reducing private investment and reducing welfare of the people", the principle of economic growth. Of course, any equitable efficiency which is "the principle opportunity for corruption in investment that underlies the implementation of sector constitutes the indifference of the investment by promoting equitable efficiency principles of investment as formulated in in an effort to create a fair, conducive and Article 3 paragraph 1 of Law no. 25 of 2007, competitive business climate", a sustainable such as legal certainty, openness, principle which is "a principle that strives to accountability, equal and non-discriminatory progress the development process through treatment, togetherness, fair efficiency, and investment to ensure prosperity and progress independence, due to several corruption in all aspects of life, both for the present and cases that have been handled by the KPK the future ", and the principle of were related to bribery in the licensing sector independence which is a principle that must which is the domain of power holders.

This has become a turning point to nation and the state by not closing itself in restore the sovereignty of existing the entry of foreign capital in order to realize investment principles through tax economic growth (Article 3 paragraph (1) reorientation that is intolerant of the letter a of Law No. 25. of 2007). corruption of persons involved in the Those principles of investment in investment process, bearing in mind that Indonesia are a connecting bridge in each of these principles has its own meaning, strengthening the role of taxes as a means of that is the principle of legal certainty which preventing corruption in the investment is "principles in the rule of law that place sector, as well as the general explanation and laws and statutory provisions as a basis in draft of the Draft Law on General Provisions every policy and action in the field of and Tax Procedures (RUU-KUP, 2016) and investment", the principle of openness which the 2015-2019 National Medium-Term 
Development Plan has emphasized that corruption in the investment process in taxation is an embodiment of the dedication Indonesia considering the existence of tax and participation of taxpayers to directly and law as the tool to detect any unofficial cost jointly to finance the country and support and unreported revenues that tend to always inclusive and equitable economic growth. transform in business communities Thus, any violation of those investment (Hermawan \& Sinaga, 2020).

principles that causes loss on state's tax

The existence of a tax institution with revenues can be interpreted that any loss of its integrity system must encourage state finance in the event of corruption and or transparent and accountable reporting bribery in the investment process refer to: a) mechanisms so that each component of Article 1 number 1 of Law no. 17 of 2003 society can act as a front line supervisor and concerning State Finances (KN Law), which ensure investment service delivery has defined state financial losses as an act organizations perform as expected (Graycar that causes losses on all rights and \& Masters, 2018), which is in line with the obligations of the state that can be valued in principles of investment which basically do money, as well as everything in the form of not tolerate any illegal act, which is the money or in the form of goods that can be actions of every person that is not only owned by the state due with the limited to acts that violate the law but also implementation of these rights and act that vilate moral, propriety, thoroughness obligations, and b) Article 2(a) of the $\mathrm{KN}$ and caution that should be owned by Law emphasizes that one of the state's rights someone in social life (Sinaga, Samekto \& is the right to collect taxes, then in the Emirzon, 2019). The meaning of illegal criminal provisions of the General Provisions activity in the investment process in and Tax Procedures Law affirms that acts Indonesia also provides an understanding of that meet the elements can cause losses on the similarity of criminal acts of corruption state revenue is a tax crime (Sinaga, 2018).

4.2. Tax Reorientation in Preventing and located tax evasion, which are equally causing losses to the country's financial or economy that cannot be separated from Corruption in Indonesia collective illegal acts, as the logic of tax

Tax reorientation as a means of evasion and corruption as collective illegal preventing corruption in the investment acts refer to the characteristics of these acts sector in Indonesia must strive to face as illegal, hidden, and collective practices challenges that cannot be separated from an make it a routine that forms a pattern of understanding of the complex and cross- organizational action that consists of rules as policy relationships that exist between a basic pattern of actors, interpretation of interrelated institutions. Historical these rules by actors and actual performance institutionalism should be a gateway to patterns (Frost \& Tischer , 2014). This reduce the possibility of political conflict that thought has also been expressed by Persson is resistant to change (Peters, Pierre \& King, et al. (2013) which states that the failure of 2005) in the form of monitoring the tax anti-corruption reforms in highly corrupt rights and obligations of every citizen who countries cannot be separated from the has the ability to prevent corruption, as the problem of collective action. Collective position of tax as part of the law State action in carrying out this corruption clearly Administration which every illegal act can results in unreported (or deliberately have consequences in the form of disguised) income, which is the domain of administrative sanctions (in the form of Article 4 paragraph (1) of Income Tax Law interest and or fines) and criminal sanctions which states that the tax object is income is (in the form of fines and prisons) (Kansil \& any additional economic capability received Kansil, 2007; Soemitro, 1992). The historical or obtained by taxpayers, both originating institutionalism approach to tax institutions from Indonesia or from outside Indonesia, can provide an elegant descriptive which can be used for consumption or for framework in creating long-term stability increasing the wealth of the relevant through its reorientation in minimizing Taxpayer, by name and in any form. Then, in 
the case of tax disincentives in the case of convenience) which is the relationship of bribery, those who give bribes clearly cannot legislation with the environment in which it charge them as costs that can reduce their applies (Maroni, 2015).

business profits, as explained in article 6 The implementation of tax paragraph (1) letter an of the Income Tax reorientation that is expected to provide Law has confirmed that the costs that can be services to the public through the charged must have a direct or indirect presentation of decisions of individuals and relationship with business activities or in the business entities that are intolerant of framework of activities to obtain, collect, and corruption in connection with an investment maintain income which is an object of tax in the future can be done through the (Eka, 2017). Whereas bribe recipients may development of several techniques that have be subject to the object of tax income in the been suggested by Graycar \& Masters form of gifts in any name or form.

(2018). First, in the event that corrupt

This terminology of "income" confirms behavior is not detected because every that tax legislation has a very important role transaction of parties that are not reported in minimizing illegal acts, especially in and or disguised is anticipated by the efforts preventing the occurrence of criminal acts of of the tax authorities to make changes to corruption through increased voluntary their efforts by making transactions compliance of taxpayers. Then, the important transparent. The DGT can carry out role of income in minimizing illegal acts has inconspicuous mechanisms through the been firmly bridged in Investment Law and collection and analysis of red flags indicating Tax Law, as the Elucidation of Article 33 corruption and at the same time tax evasion paragraph (3) of Investment law defines tax and or tax avoidance in an investment crime as incorrect and/or incomplete data process, which of course must involve and information in tax filing that cause harm technology in reducing discretion in to the state's tax revenues and as the Article conducting illegal transactions and in 1 number (1) of the KUP Law formulating marking symptoms of irregularities taxation taxes as "mandatory contributions to the state norms. Second, in anticipating transaction owed by individuals or entities that are anonymity in the books or records of parties coercive based on the Act, with no direct related to the investment process, the DGT compensation and used for the state's can apply to change the risk and reward with purposes for the greatest prosperity of the reduced anonymity. Anonymity reduces people", so that all taxpayers must obtain accountability, where, for example, fairness through their participation right to unscrupulous officers who deal with the report certain taxpayers who commit tax investment will conceal as much of their fraud. The central role of legislation in tax decisions as possible regarding a particular reinforcement as a means of preventing investment. In addition, anonymous corruption refers to its definition as any transactions or records will make it difficult written decision issued by an official or for complaints that are the right of every environmental authority that contains citizen in the event of bribery and/or generally binding rules (behavior), bearing in corruption. Third, in the case of collusion mind that legislation has two functions at between individual government officials and once, that is the internal function which is individual persons in investment companies the function of legislation as a legal sub- that are clearly not in line with the principles system of legislation on the rule of law of equality, justice, and information system in general (which includes the disclosure, the tax authority can instill value function of law creation, the function of legal integrity by delivering integrity. Every reform, the function of integrating the legal individual and business entity involved in the system pluralism and the function of legal process of investment is a taxpayer whose certainty) and the external function (or can data is stored in the DGT data center, which be called the social function of the law, will certainly be able to eliminate their which includes: the function of change, the integrity as taxpayers who must report all function of stabilization, and the function of their tax rights and obligations with 
certainty, truth, and clearly. That integrity authority to create active participation of will be tarnished if the DGT has each taxpayer constitutes the form of implemented law enforcement on the consistency in implementing transparency, perpetrators of these illegal acts. And even, accountability, and excellent service that will the sanctions that have been attached to the narrow the space for the perpetrators of taxpayers will be one of the "clean checks" corruption, collusion, and tax evasion due to for other institutions related to the integrity the increase of voluntary compliance of of certain individuals or business entities taxpayers who are intolerant for any form of related to investment. Fourth, in narrowing corruption and collusion.

the space for corruptors and tax evasion actors, the tax authority must be able to increase the awareness of taxpayers by alerting peoples' conscience. Voluntary compliance of taxpayers is direct community involvement, which is identical with active participation as taxpayers in state life, as one of the functions of tax is related to the idea or conception of democracy. The concept of democracy as the active participation of taxpayers in development is in line with several principles of investment and the thinking of Sodikin (2014) which argues that there are three ideas that are interrelated in building democracy, that are freedom, equality, and justice, where freedom or independence is recognized as the main goal of every state in independence contained human demands not to be controlled by anyone, and ultimately requires a basis of equality to bring justice. Tax reorientation that encourages the active participation of all taxpayers has been investigated is expected to be in line with the Buckenmaier, Dimant, and Mittone (2018) studies that investigate the effects of institutional mechanisms that encourage taxpayers to blow the whistle on collusive corruption and tax compliance. His findings state that in the presence of legal mechanisms, subjects collude and receive bribes less frequently when paying more taxes, and the introduction of opportunities to blow the whistle will reduce collision and acceptance of bribes and increase the tax returns collected.

Those history of several existing laws and various expert notions have shown that the tax authority is more effective in monitoring and reducing the resistance of investment in Indonesia.

each collective illegal acts of corruption and collusion actors in the investment sector in Indonesia. Preventive and curative control of the parties involved in an investment process which followed by strong efforts of a tax

\section{Conclusions}

This study concludes that tax reorientation can prevent corruption in investment sector in Indonesia, as the ability of tax law in detecting any unofficial cost and unreported revenues has strong relation with investment principles consisting of legal certainty, openness, accountability, equal and nondiscriminatory treatment, togetherness, fair efficiency, and independence. The historical institutionalism approach involves the DGT continuously supervising closely and periodically any additional economic capacity in whatever name and form with respect to each taxpayer (including every individual and business entity involved in the investment process in Indonesia through the mandate of laws and regulations. tax invitation). Although it will restrict the actors involved in investment, the existing limitation is the design of a system that can influence individuals and groups to prevent corruption. It is proposed that tax authority restrictions can be applied in a number of ways, such as applying bribes as nondeductible expenses and as an income tax object from gifts to givers, applying bribes as income to recipients, recommending noncriminal sanctions due to the useful and efficient financial/monetary sanctions in returning losses of the state's tax revenue (Priyambudi, Sinaga \& Bolifaar, 2020), and as a center for net check recommendations for other institutions (such as regional governments, BKPM, banking) towards individuals and business entities involved in 


\section{References}

Abimanyu, A. 2009. Era Baru Kebijakan Fiskal. Jakarta: PT. Kompas Media Nusantara

Akbar, S. 2018. Terjaring OTT, Kadis Penanaman Modal Padang Lawas Terancam Hukuman 20 Tahun Penjara. Available at: https://medan.tribunnews.com/2018/05/30/ terjaring-ott-kadis-penanaman-modalpadang-lawas-terancam-hukuman-20tahun-penjara. Accessed on February 23, 2020.

Breslita, T.P. \& Samanta, S.K. 2008. Investment Himawan, C. 2003. Hukum Sebagai Flows, Economic Growth, and Corruption in African Countries: An Analysis. Journal of African Business 9(2): 287- 307.

Buckenmaier, J., Dimant, E. \& Mittone, L. 2018. Effects of institutional history and leniency on collusive corruption and tax evasion. Available at: https://www.econstor.eu/bitstream/10419/2 00424/1/1024726800.pdf. Accessed on March 3, 2020.

Eka, I.W.A. February 16, 2017. Pajak dalam pemberantasan korupsi. Available at: https://m.kontan.co.id/news_analisis/pajakdalam-pemberantasan-korupsi. Accessed on March 3, 2020.

Goddard, W. \& Melville, S. 2007. Research Methodology: An Introduction.

Lansdowne: Juta \& Co. Ltd.

Frost, J. \& Tischer, S. 2014. Unmasking Collective Corruption: The Dynamics of Corrupt Routines. Eurepean Management Review 11(3-4): 191-207.

Graycar, A. \& Masters, B. 2018. Preventing malfeasance in low corruption environments: twenty public administration responses. Journal of Financial Crime 25(1): 170-186.
Haque, M.E. \& Kneller, R. 2015. Why does

Public Investment Fail to Raise Economic Growth? The Role of Corruption. The Manchester School 83(6): pp. 623-651.

Hermawan, A.W. \& Sinaga, H.D.P. 2020. Public Benefit Principle in Regulating ECommerce Tax on Consumer's Location in Indonesia. International Journal of Advanced Science and Technology 29(8): 1212-1222. Retrieved from http://sersc.org/journals/index.php/IJAS T/article/view/20137.
Panglima. Jakarta: Kompas.

Kansil, C.S.T. \& Kansil, C.S.T. 2007. Latihan Ujian: Pengantar Hukum Indonesia. Jakarta: Sinar Grafika.

KBBI, 2020. Orientasi. Jakarta: Kamus Besar Bahasa Indonesia. Available at: http://kamusbahasindonesia.org/orientasi .KamusBahasaIndonesia.org. Accessed on January 30, 2020.

KPK 2020. Jejak Kasus. Jakarta: Komisi Pemberantasan Korupsi. Available at: https://acch.kpk.go.id/id/jejak-kasus/84theo-f-toemion. Accessed on January 30, 2020.

Lowndes, V. 2010. The Institutional Approach. In Marsh, D. \& Stoker, G. Eds. Theory and Methods in Political Science. New York: Palgrave Macmillan, pp. 61-64.

Maroni. 2015. Pengantar Hukum Pidana Administrasi. Lampung: CV. Anugrah Utama Raharja.

Mauro, P. 1995. Corruption and Growth. The Quarterly Journal of Economocs 10(3): 681-712. 
Okada, K. \& Samreth, S. 2014. How Does Corruption Influence the Effect of Foreign Direct Investment on Economic Growth? Global Economic Review: Perspectives on East Asian Economies and Industries 43:3: 207-220.

Persson, A., Rothstein, B. \& Teorell, J. 2013. Why Anticorruption Reforms FailSystemic Corruption as a Collective Action Problem. Governance 26(3): 449-471.

Peters, B.G., Pierre, J. \& King, D.S. 2005. The Politics of Path Dependency: Political Conflict in Historical Institutionalism. Journal of Politics 67(4): 1275-1300.

Priyambudi, Sinaga, H.D.P. \& Bolifaar, A.H. 2020. Managing Plea Bargaining Risk in Indonesia: An Effort to Overcome the Corporate Corruption. Tes Engineering \& Management 83(March-April): 1199312005 .

Purbaya, A.A. 2019. 80\% Penindakan KPK Berupa Kasus Suap di Bidang Perizinan. Available at: https://news.detik.com/beritajawa-tengah/d-4492505/80-penindakankpk-berupa-kasus-suap-di-bidangperizinan. Accessed on February 23, 2020.

Robson, C. \& McCartan, K. 2016. Real World Research: A Resource for Users of Social Research Methods in Applied Settings. London: John Wiley \& Sons Ltd.

RUU-KUP. (2016). Naskah Akademik Rancangan Undang-Undang Ketentuan Umum dan Tata Cara Perpajakan. Jakarta: Kementerian Keuangan.

Saputri, D.S. \& Risalah, D.F. 2017. Jokowi: Banyak Regulasi Justru Picu Korupsi. Available at: https://nasional.republika.co.id/berita/p0t19 x440/jokowi-banyak-regulasi-justru-picukorupsi. Accessed on February 22, 2020.
Shih, M-C., Sun, M.T-W., \& Wang, G-X. 2012. The historical institutionalism analysis of Taiwan's administrative reform. International Review of Administrative Sciences 78(2) 305-327.

Sinaga, H.D.P., Samekto, F.X.A. \& Emirzon, J. 2019. Ideal Corporate Criminal Liability for the Performance and Accreditation of Public Accountant Audit Report in Indonesia. International Journal of Economics and Business Administration 7(4): 451-463.

Sinaga, H.D.P. 2018. Loss (of Revenue) of State within Taxation Crimes in Indonesia. Mimbar Hukum 30(1): 141155.

Sodikin 2014. Hukum Pemilu, Pemilu Sebagai Praktek Ketatanegaraan. Bekasi: Gramata Publishing, Bekasi.

Soemitro, R. 1992. Pengantar Singkat Hukum Pajak. Bandung: Eresco.

Supancana, I.B.R., Putra, I.B.W., Sugondo, F., Usman, M. \& Sulistyani, S. 2010. Ikhtisar Ketentuan Penanaman Modal. Jakarta: The Indonesia Netherlands National Legal Reform Program.

Suparno, A. 2015. Praktek Korupsi dalam Investasi. Available at; https://www.kompasiana.com/ahmadsupar no1982/566991d70323bd9810ead57d/pra ktek-korupsi-dalam-investasi?page=all. Accessed on January 27, 2020.

Weathington, B.L., Cunningham, C.J.L., \& Pittenger, D.J. 2012. Understanding Business Research. New Jersey: John Wiley \& Sons, Inc. 